\title{
Integrating Resistivity Techniques for Optimum Groundwater Exploration and Development within a Hotel Facility in Osogbo, Southwestern Nigeria
}

\author{
${ }^{*}$ OJO, A; ${ }^{2}$ BABAFEMI, E; ${ }^{3}$ FALEYE, E; ${ }^{1}$ SHADO, O \\ ${ }^{*}$ Department of Geological Science, Osun State University, Osogbo, Nigeria. \\ ${ }^{2}$ Geobabs Integrated Services, Lagos, Nigeria \\ ${ }^{3}$ Department of Physical and Chemical Sciences, Elizade University, Ilara-Mokin, Nigeria \\ *Corresponding Author Email: adeolu.ojo@uniosun.edu.ng; Tel: +2348035626912; Other Authors Email: \\ emmanuelmuyiwa32@gmail.com; emmanuel.faleye16@gmail.com; shadoolawale@gmail.com
}

\begin{abstract}
This work is an attempt to combine dipole-dipole profiling and vertical electrical sounding techniques of electrical resistivity methods to investigate the groundwater potential within the premises of a 3-star hotel facility in Osogbo, Nigeria by delineating the geoelectric layers, delineating the low resistivity layers, determining the lithologies and hence, delineating the groundwater bearing zones. The five vertical electrical sounding data were collected along two pre-surveyed dipole-dipole traverses at right angle to each other beside the fences of the premises using the ABEM SAS $300 \mathrm{c}$ terrameter. The observed data were interpreted quantitatively using curve matching and computer-assisted iteration method using the WinResist and Dipro software. The results of the inversion show that the lithology comprises of the top soil and an intermittent sequence of sand and lateritic clay having varying resistivity and thickness. The aquiferous layer was observed to be located at a depth of $23 \mathrm{~m}$ to $25 \mathrm{~m}$ due to the low resistivity and high thickness of the aquiferous layer. The result of the 2-D imaging closely correlates with the result of the vertical electrical sounding. Thus, combining these techniques in groundwater investigation has achieved similar result as the Werner technique and has reduced ambiguity and error in positioning for drilling.
\end{abstract}

DOI: https://dx.doi.org/10.4314/jasem.v25i2.15

Copyright: Copyright $\odot 2021$ Olabanji et al. This is an open access article distributed under the Creative Commons Attribution License (CCL), which permits unrestricted use, distribution, and reproduction in any medium, provided the original work is properly cited.

Dates: Received: 12 December 2020; Revised: 26 January 2021; Accepted: 12 February 2021

Keywords: Resistivity, Groundwater Exploration, Dipole-Dipole

The use of groundwater in virtually all sectors of human endeavor cannot be over-emphasized. Hotel and tourism industry are not left alone in this quest for groundwater resources. Hotel and resorts centers in recent times constitute large users of water (Tang 2012, Bohdanowicz, 2005). The World Travel and Tourism Council (WTTC) in 2013 noted that the travel and tourism industry has outperformed the global economy; growing faster than manufacturing, retail, financial services and communications. This is due to increasing number of hotels, motels and guest houses constructed to meet the need of tourists worldwide. Hotels and guest houses possess a number of facilities and provide a variety of functions that requires the use of large amount of water. They are normally operated 24 hours a day throughout the year (Deng \& Burnett, 2002). Therefore, a considerable amount of water is required for daily operation in its various functional areas such as laundry, kitchens and guestrooms, restaurants, public areas, swimming pools to name a few. The composition of a hotel's water consumption in Germany, for instance, can be presented as $34 \%$ guest rooms, $22 \%$ kitchen, $20 \%$ public bathrooms, $17 \%$ laundry, $1 \%$ heating, ventilating and air conditioning, $4 \%$ steam generation and $2 \%$ for swimming pool (ITP, 2008; Silva-Afonso \& PimentelRodrigues, 2011). A tourist's water consumption is higher than a resident's water consumption (Styles $e t$ al. 2013). A European tourist consumes around 300 litres of water per day compared with a European resident consumption of 100-200 litres per day, averaging approximately 150 litres (Gössling et al. 2011). The average medium to large hotel uses 79,000 litres per day or 301 litres per room, which is the equivalent of using 29 Olympic pools of water each year (Smart Water Fund, 2007). In the Philippine hotels, water consumption is about 1,800.252 litres per day and this amount of water can support fourteen people at their current standard of living (Kim, 2005). Further, sustainability is increasingly becoming one of the most relevant issues to hoteliers in the $21^{\text {st }}$ century as costs continue to rise, demand becomes 
increasingly sensitive and the pressure on being economically, socially and environmentally responsible grows (Bader, 2005). Therefore, conserving water should be an important priority for hotels. Apart from the environmental and social benefits, improved water use and direct water saving can also make a noticeable difference to a hotel's bottom line (Deng \& Burnett, 2002).

Most times, most workers combine the Werner array profiling survey with the vertical electrical sounding technique in groundwater investigation and end up sounding points of low resistivity on the Werner profiles. This research desire to combine other resistivity technique in the place of the Werner technique. The aim of carrying out this research is to investigate if any other method would achieve similar result as the Werner approach in locating appropriate areas within the premises of the 3-star hotel that would yield groundwater in economic quantity for consumption of local and international tourists that would use the facility.

\section{MATERIALS AND METHOD}

Location of The Study Area: The study area is located within the premises of a 3-star hotel facility at OwodeIlesha at the suburb of Osogbo township along IleshaOsogbo road. (Figure 1). Osogbo is a state capital of Osun State and possesses a population density of about 500 people/square meter (Adegoke and Sojobi (2015). It is bordered by the following coordinates: N07.738316, E004.586367/N07.737903, E004.586726 and between N07.738320, E004.587068/N07.738680, E004.586829. Geologically, the study area is underlain by the PreCambrian basement complex rock of the western Nigeria schist belt which lies within the Pan-African mobile belt, east of the West African craton. The belt is believed to be divided into the frontal region and the internal region and Nigeria is located in the internal region which was affected by deformation and thermal reactivation during the Pan African Orogeny ${ }^{13}$. The Nigerian basement rocks are thought to result from at least four major orogenic cycles of deformation, metamorphism and remobilization, corresponding to the Liberian $(2,700 \pm 200 \mathrm{Ma})$, the Eburnean $(2,000 \pm$ $200 \mathrm{Ma})$, the Kibaran (1,100 $\pm 200 \mathrm{Ma})$ and the PanAfrican $(600 \pm 150 \mathrm{Ma})$ orogenies (Ajibade et al. 1987). Local geology is typical of the geology of Ilesha schist belt which is composed primarily of banded gneiss to the south eastern part and schist to the western part. The climate of the study area also is typical of the climate of the western part of Nigeria, a tropical climate with a tropical rain forest (Akpootu and Rabiu, 2019). The climate has more wet season months that run from April to October every year than the dry season months which run from November to
March each year. The climate around the study area has been classified as Aw (tropical wet and dry or savanna) according to the Köppen-Geiger climate classification, an indication of a tropical wet and dry or savanna having an extended dry season where precipitation during the wet season is usually less than 1000 millimeters, and only during the summer season. Average annual temperature in in the study area is about $27{ }^{\circ} \mathrm{C}$ while the average annual rainfall is about $1300 \mathrm{~mm}$. On a yearly basis, every January records the least amount of rainfall although precipitation peaks every September with an average of $222 \mathrm{~mm}$. On the average, the highest temperature is about $33^{\circ} \mathrm{C}$ around March while the coldest month is about $21{ }^{\circ} \mathrm{C}$ on average around August every year. The study area is drained by an offshoot of a bigger River Osun which runs along the eastern part of the study area in NorthEast- South-West direction. The river separates between Osun-Jela village from Osogbo metropolis. Smaller rivers as well as drainages from local culverts all empty their contents into the river.

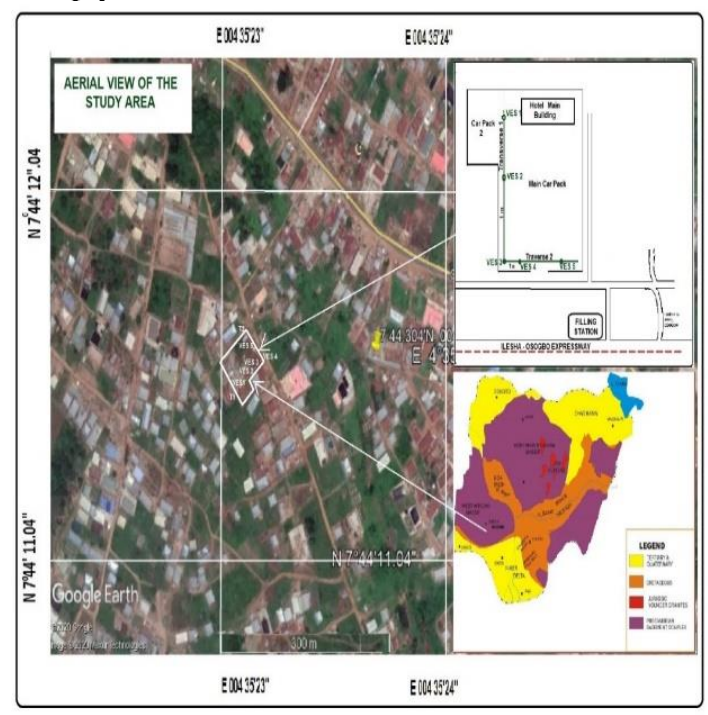

Fig 1: Modified Location Map of the Study Area showing the VES Positions (modified after Opara et al. 2015)

The investigation involved the use of the ABEM SAS $300 \mathrm{c}$ resistivity equipment with associated accessories including the Garmin Global Positioning System (GPS) which was employed to record the geographic coordinates of each VES positions. Total length of transverse 1 and 2 were $110 \mathrm{~m}$ and $70 \mathrm{~m}$ respectively. The investigation employed the 2-D imaging techniques and the vertical electrical sounding techniques, both of electrical resistivity method. An Lshaped traverse was established within the study area such that it runs 1-meter away from the fence but within the hotel premises. One dipole-dipole survey each was carried out along traverse 1 and traverse 2, because it gives good information of the subsurface in 
both vertical and horizontal directions (Ward, 1990). During the dipole-dipole survey, direct current was injected into the subsurface with current dipole $(\mathrm{C} 1$ and $\mathrm{C} 2$ ) and resulting ground voltage measured with the potential dipole ( $\mathrm{P} 1$ and $\mathrm{P} 2)$. Increase in separation between the dipoles $(\mathrm{C} 1-\mathrm{C} 2$ and $\mathrm{P} 1-\mathrm{P} 2)$ results to increase in depth of investigation (Anudu et al. 2012). The inter-electrode spacing (a) $=10 \mathrm{~m}$ was employed, whereas the expansion factor (n) was varied from 1 to 5 . The apparent resistivity values obtained were plotted on a depth section along intersecting $45^{\circ}$ beneath the centre of the dipoles. The apparent resistivity $\left(\rho_{a}\right)$ in ohm meters at each dipole separation (Barker, 2007, Seidel and Lange, 2007) was calculated using equation given by

$$
\rho_{a}=\operatorname{\pi an}(n+1)(n+2) R
$$

where $\mathrm{a}$ is inter-electrode spacing, $\mathrm{n}$ is expansion factor and $\mathrm{R}$ is resistance which is voltage (V) divide by current (I). Points 1, 2, 3, 4, and 5 of resistivity lows were selected on each dipole-dipole traverse (profiles) and these points served as points for carrying out the vertical electrical soundings (VES) survey. The sounding surveys were carried out over a maximum electrode spacing of 210 metres along traverse 1 and 140 metres in traverse 2. Points of VES 1, VES 2, VES 3 were all selected along the first traverse while the points VES 4 and VES 5 were selected along the second traverse situated perpendicular to the first traverse (Figure 1). The VES sounding data acquired were subjected to analysis and iterative modeling to identify the layer resistivity and layer thickness (both known as geoelectric parameters) of each layer and lithology inferred from these parameters were used to delineate the aquiferous layer using the Excel spread sheet and WinResist software.

\section{RESULTS AND CONCLUSIONS}

Results of interpreted resistivity data for the investigation are presented as curves, tables, geoelectric sections and 2-D resistivity profile image. The curve types obtained from the interpreted VES data are 5-layer with QHA (VES 1), KHAA (VES 2), QQH (VES 3), KHA (VES 4) and KQH (VES 5). This is as shown in Figures 2 to 5. Computer interpretation of the observed curve resolved the penetrated layers beneath each VES into five (5) in all the VESes except in VES 2 where it was resolved into six (6) geoelectric layers (Figure 3). Table 1 represent the summary of the results obtained from the analysis and interpretation of the vertical electrical sounding data. Figure 6 represent the geo-electric sections obtained from the results in Table 1. However, figures 7 and 8 shows the 2-D inversion image of the subsurface correlated with the geo-section column along the profile.

Table 1: Summary Table of all Interpreted VES data

\begin{tabular}{llllll}
\hline VES No & $\begin{array}{l}\text { Geoelectric } \\
\text { Layer }\end{array}$ & $\begin{array}{c}\text { Resistivity } \\
(\mathbf{\Omega m})\end{array}$ & $\begin{array}{c}\text { Thickness } \\
(\mathbf{m})\end{array}$ & $\begin{array}{c}\text { Depth } \\
(\mathbf{m})\end{array}$ & Lithology \\
\hline VES 1 & 1 & 563.8 & 1.1 & 1.1 & Topsoil (lateritic) \\
& 2 & 250.3 & 12.1 & 13.2 & Sandy layer \\
& 3 & 209.8 & 9.8 & 23.0 & Weathered layer \\
& 4 & 379.8 & 14.5 & 37.5 & Fractured Basement \\
VES 2 & 5 & 897.6 & - & - & Fresh Basement \\
& 1 & 319.4 & 1.7 & 1.7 & Topsoil \\
& 2 & 642.3 & 1.4 & 3.1 & Lateritic layer \\
& 3 & 159.3 & 14.9 & 18.0 & Weathered layer \\
& 4 & 416.5 & 11.7 & 29.7 & Fractured Basement \\
& 5 & 621.1 & 19.0 & 48.7 & Basement Rock \\
VES 3 & 6 & 1258.8 & - & - & Fresh Basement Rock \\
& 1 & 308.5 & 1.1 & 1.1 & Topsoil (lateritic) \\
& 2 & 257.9 & 4.5 & 5.6 & Sandy layer \\
& 3 & 191.8 & 5.5 & 11.2 & Weathered layer \\
& 4 & 144.7 & 12.7 & 23.8 & Fractured Basement \\
VES 4 & 5 & 572.2 & - & - & Basement Rock \\
& 1 & 311.5 & 0.5 & 0.5 & Topsoil \\
& 2 & 2148.7 & 1.6 & 2.1 & Lateritic hardpan \\
& 3 & 168.0 & 4.6 & 6.7 & Weathered Basement \\
& 4 & 79.6 & 12.2 & 18.9 & Fractured Basement \\
& 5 & 2397.5 & - & - & Fresh Basement \\
VES 5 & 1 & 250.3 & 1.0 & 1.0 & Topsoil (lateritic) \\
& 2 & 1631.7 & 2.4 & 3.4 & Lateritic hardpan \\
& 3 & 267.0 & 2.7 & 6.0 & Weathered Basement \\
& 4 & 90.4 & 10.5 & 16.5 & Fractured Basement \\
& 5 & 932.7 & - & - & Fresh Basement Rock \\
\hline
\end{tabular}




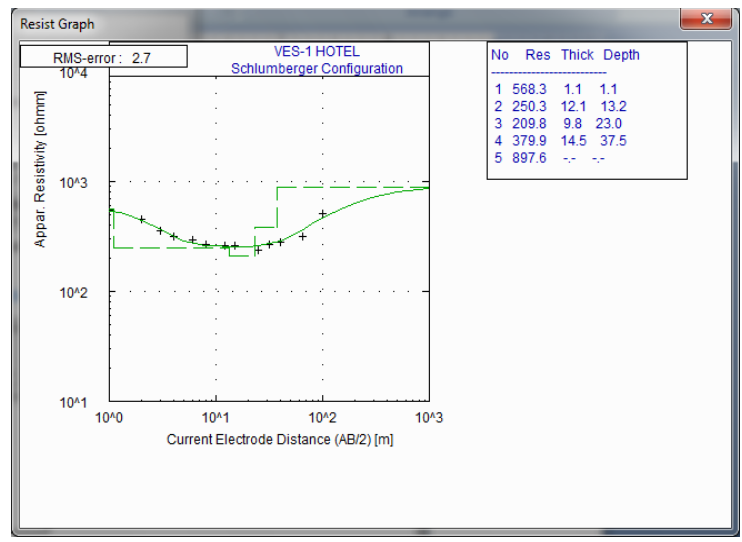

Fig 2. Iterative Curve in VES 1

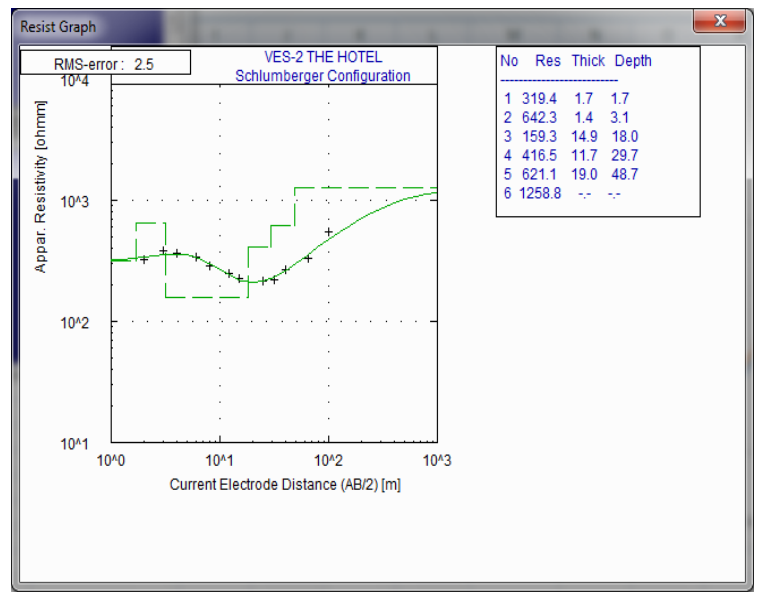

Fig 3: Iterative Curve in VES 2

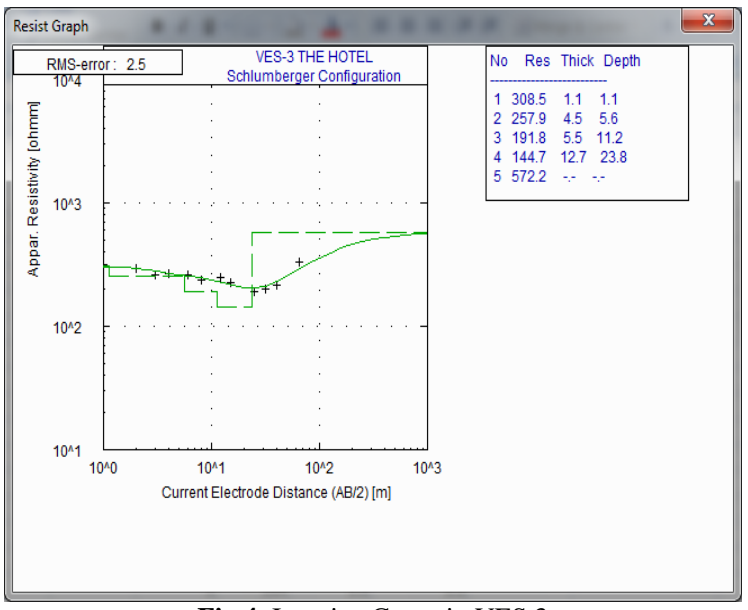

Fig 4: Iterative Curve in VES 3

Geoelectric Section: The geo-electric section generated for the data obtained from VES 1, VES 2, VES 3, VES 4 and VES 5 is as shown in Figure 6. The geoelectric section is represented in $3 \mathrm{D}$ showing the orientation of the two traverses perpendicular to each other. The section clearly reveals a relatively thin layer of resistive materials as the topsoil, with resistivity ranging from 308 to $563 \Omega \mathrm{m}$ and approximate thickness ranging from 1.1 to $1.7 \mathrm{~m}$.

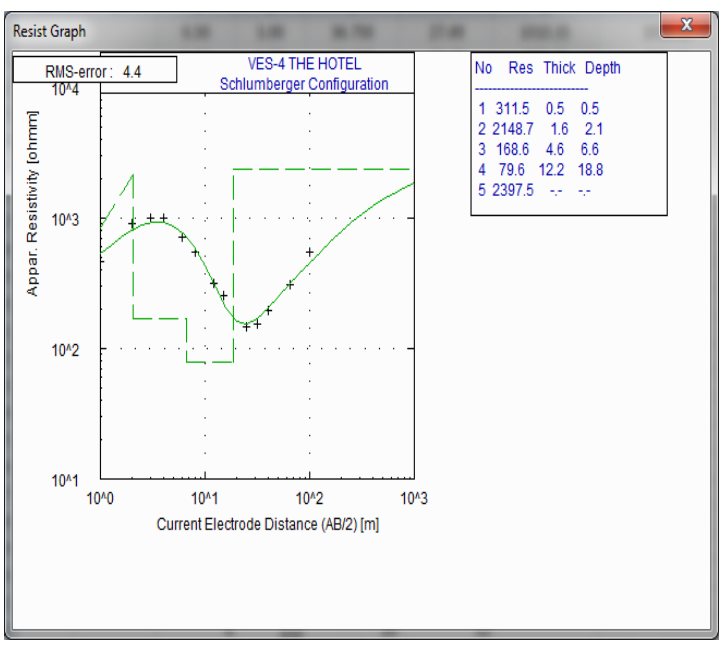

Fig 5: Iterative Curve for VES 4

This highly resistive formation is thought to compose of lateritic formation which dominates and overlie the area. Underlying this unit is a layer exhibiting resistivity variations which ranges from $250 \Omega \mathrm{m}$ to $642 \Omega \mathrm{m}$ with an increasing thickness from $1.4 \mathrm{~m}$ at VES 2 to $12.5 \mathrm{~m}$ at VES 1, toward the northeastern part of the study area (Figure 1).

It represents the sand clayey sand layer. The third layer seem to have lower resistivity compared to the second geo-electric layer with resistivity value ranging from $151 \Omega \mathrm{m}$ at VES 2, $191 \Omega \mathrm{m}$ at VES 3 and $209 \Omega \mathrm{m}$ at VES 1. This layer is the weathered layer, which has hydrogeological significance with groundwater prospect. Below the weathered unit, fractured basement layer is observed at a depth of $14.5 \mathrm{~m}$ in VES $1,19 \mathrm{~m}$ in VES 2 and $12.7 \mathrm{~m}$ in VES 3 and this layer lies directly above the fresh basement whose thickness is undetermined. On the second traverse as well, the topmost topsoil layer was observed to be relatively thin, with thickness of about $0.5 \mathrm{~m}$ in VES 4 to $1.0 \mathrm{~m}$ in VES 5.

The aquifer layer along this traverse, as clearly displayed in Figure 5, commences at a depth of $6.7 \mathrm{~m}$ to $18.9 \mathrm{~m}$ in VES 4 and a depth of $6.0 \mathrm{~m}$ to depth of $16.5 \mathrm{~m}$ at the top of the fresh basement. Lateritic hardpan of resistivity values of $2148.7 \Omega \mathrm{m}$ and 1631.7 $\Omega m$ directly overlie the aquiferous layer at VES 4 and VES 5 respectively. Along this traverse, VES 4 position show evidence of groundwater potential. However, due to the fact that the water bearing layer is located at shallow depth, the point can only be suited 
for construction of hand-dug well rather than a borehole.

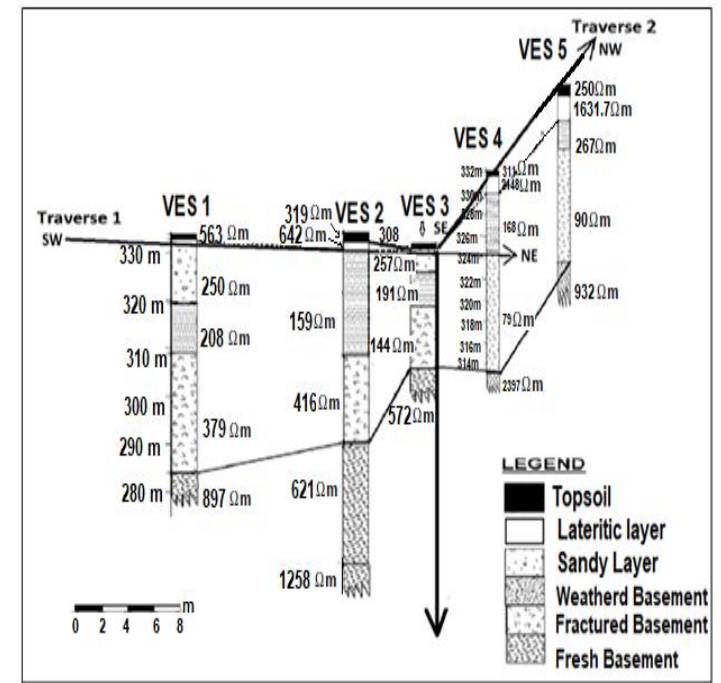

Fig 6: Geoelectric section generated for the data obtained from VES 1, VES 2, VES 3, VES 4 and VS 5.

Pseudo-Section 1: The first traverse was located towards the southern part of the premises but runs in the NE-SW direction within the investigated premises. Pseudo section 1 was obtained by carrying out 2D inversion of dipole-dipole profiles along the traverse 1 (Figure 4). Three VES soundings were carried out along traverse one, out of which two of the VES showed good groundwater potential (portion coloured with deep blue and green). Interpretation of the pseudo-section revealed two groundwater productive areas having resistivity values of as low as $209 \Omega \mathrm{m}$ within the weathered layer and $379 \Omega \mathrm{m}$ within the fractured basement layer. The two points were observed to be potentially productive at depths of 23 $\mathrm{m} \mathrm{n} \mathrm{VES} 1$ and $18 \mathrm{~m}$ in VES 2. This is as shown in Figure 5 (blue portion of the pseudosection). The aquiferous layer was observed to have been overlain by a relatively high resistivity sandy layer of about $209.8 \Omega \mathrm{m}$ in VES 1 and a fairly high resistivity lateritic layer of about $642.3 \Omega \mathrm{m}$ in VES 2. (Table 1). Pseudo-Section 2: The pseudo-section represents the inversion of the dipole-dipole along traverse 2 (Figure $5)$. The traverse trend in the NW-SE direction and perpendicular to traverse 1 . The inverted section (Figure 5) clearly shows a general resistivity variation that ranges from about $65 \Omega \mathrm{m}$ to as high as $4183 \Omega \mathrm{m}$. At VES 4, there exist a low resistivity layer at shallow depth (blue colour) having a resistivity of about 168 $\Omega \mathrm{m}$ at a depth of $6.7 \mathrm{~m}$. (Table 1). This also continues to a depth of $18.9 \mathrm{~m}$ where the resistivity drops down to $79.6 \Omega \mathrm{m}$. These two regions constitute the weathered layer which seats conformably on the basement rock in the studied area. The resistivity modeled data lying within these two zones are inferred as the prospect and potential groundwater zone (blue portion on the inverted section Figure 5).

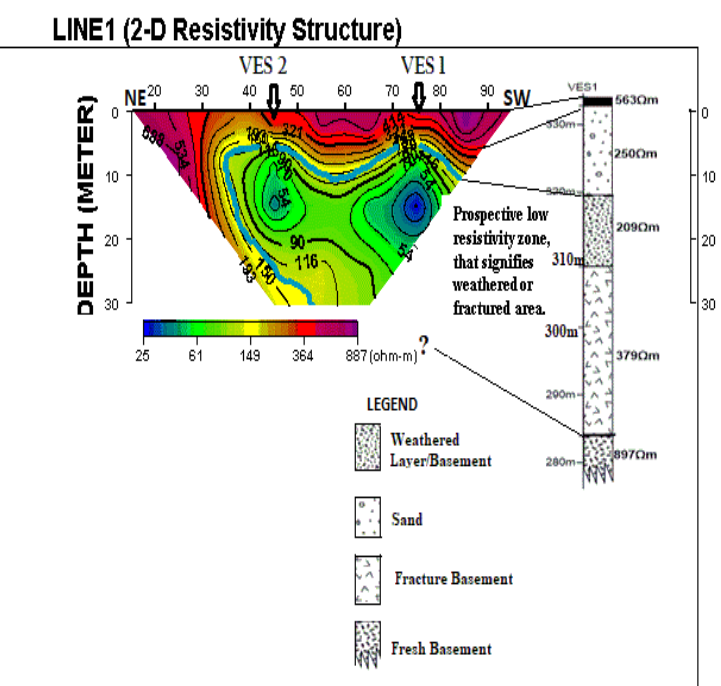

Fig 7: Combined Pseudo-section and Geo-section along Traverse 1

LINE2 (2-D Resistivity Structure)

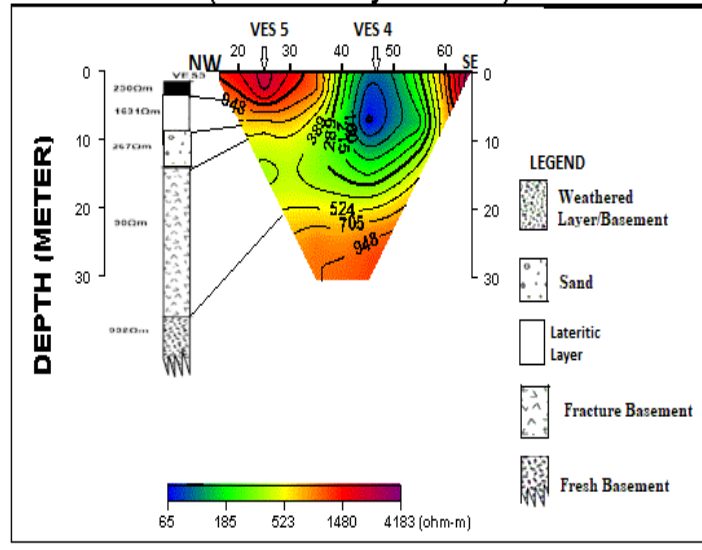

Fig 8: Pseudo section along Traverse 2

Conclusions: Integrated geophysical investigation was carried out within the premises of a 3-star hotel, in Owode-Ilesha in the suburb of Osogbo using the combined VES technique and 2-D imaging techniques of electrical resistivity method with the aim of delineating the depth to groundwater within the hotel facility. The result of the investigation revealed that the water-bearing aquiferous layer is at a depth of 23 $\mathrm{m}$ in VES 1 while it is at a depth of $11.2 \mathrm{~m}$ in VES 3. The result obtained from the geophysical investigation using the two approaches generally correlate with one another by revealing significant variations of electrical resistivity measurement of the subsurface.

Acknowledgements: The authors wish to appreciate the students of the Department of Geological Sciences, Osun State University, Osogbo who assisted during 
the acquisition of data and field survey. We also appreciate the staff of Geobabs Resources for providing the needed logistics during the data acquisition stage. We do not forget the immense contributions of anonymous reviewers who reviewed the manuscript.

\section{REFERENCES}

Adegoke CW, Sojobi AO. (2015) Climate Change Impact on Infrastructure in Osogbo Metropolis, South-West Nigeria. J Emerging Trends in Eng. Applied Sci; 6(3): 156-65. [JETEAS].

Ajibade, AC.; Rahaman, MA; Woakes, M. (1987): Proterozoic Crustal Development in the PanAfrican Regime of Nigeria. Ilp Working Group 3 Mid-Term Report

Akpootu DO; Rabiu AM. (2019). Empirical Models for Estimating Tropospheric Radio Refractivity Over Osogbo, Nigeria; The Open Atmospheric Science Journal; ISSN: 1874-2823 - Volume 14,2020

Anudu GK; Essien BI; Obrike SE (2012), Hydrogeophysical investigation and estimation of groundwater potentials of the Lower Paleozoic to Precambrian crystalline basement rock of Keffi area, north-central Nigeria using resistivity method, Arabian J. Geosciences, 7, 311-322

Bader, EE. (2005). Sustainable hotel business practices. J. Retail \& Leisure Prop. 5(1), 70-77.

Barker RD (2007). Electrical resistivity methods for borehole siting in hardrock region. In: Thangarajan M (ed) Groundwater: resource evaluation, augmentation, contamination, restoration, modeling and management. Springer, Dordrecht, p 357

Bohdanowicz, P; Simanic, B.; Martinac, I. (2005). Sustainable hotels-environmental reporting according to green globe 21, Green Globes Canada/GEM UK, IHEI benchmark hotel and Hilton environmental reporting. in Sustainable Building (SB05) Vol. 27, p. 29).

Deng, SM.; Burnett, J. (2002). Water use in hotels in Hong Kong. Inter. J. Hospitality Manag. 21(1), 57-66.
Gössling Stefan ; Paul PC; Jean-Paul MH; Ceron GD; La Vergne; Lehmann DS (2011). Tourism and water use: Supply, demand, and security. An international review, Tourism Management, 33 (1), February 2012, Pages 1-15.

International Tourism Partnership (2008). Environmental Management for Hotels, London, International Tourism Partnership.

Kim, S. (2005). An investigation into hotel employees' perception of green practices. (Unpublished Thesis, Master of Science in Tourism and Hospitality Management). University of Central Florida, Orlando, Florida.

Opara AI; Udoete RL; Emberga TT; Echetama HN; Ugwuegbu IE; Nwokocha KC; Ijeoma $\mathrm{KC}$; Chinaka JC; Onyema JC (2015) Structural Interpretation of The Jos-Bukuru Younger Granite Ring Complexes Inferred from LandsatTm Data; J. Geosci. Geomatics. 3(3), 56-67

Seidel K; Lange G (2007). Direct current resistivity method. in: Knodel K, Lange G, Voigt HJ (eds) Environmental geology: handbook of field methods and case studies. Springer, Berlin, $\mathrm{p}$ 1339.

Silva-Afonso, A; Pimentel-Rodrigues, C. (2011). The importance of water efficiency in buildings in Mediterranean countries. The Portuguese experience. Inter. J. Systems Applications, Engineering \& Development, 1(5), 17-24.

Smart Water Fund. (2007). Water wise hotels: Toolkit, March 2007, Melbourne": Melbourne City Council.

Styles, D.; Schönberger, H.; Martos, L.G. (2013) Best Environmental Management Practice in the Tourism Sector. European Union, p721.

Ward, SH (1990). Resistivity and induced polarization methods. In: Geotechnical and Environmental Geophysics, SH Ward (ed). Investigations in geophysics; (5)1: Review and tutorial, Society of Exploration Geophysics Tulsa, Oklahoma, pp. 147-189

Tang, FE. (2012). A Study of Water Consumption in Two Malaysian Resorts. World Acad. Sci. Engineer. Technol. 68, 1162-1167. 